\author{
Burkholderia gladioli pv. alliicola $\mathrm{CH1}$ 의 병원성 및 \\ Polygaractronase Isozymes 생성 \\ 이찬중* - 이종태 ${ }^{1} \cdot$ 김영태 $^{2} \cdot$ 전창성 - 정종천 · 박 완 ${ }^{3}$ \\ 국립원예특작과학원 버섯과, ${ }^{1}$ 경남농업기술원 양파연구소, ${ }^{2}$ 국립농업과학원 유전자분석개발과, \\ 3경북대학교 생명과학부
}

\title{
Phytopathogenicity of Burkholderia gladioli pv. alliicola CH1 and Production of PGase Isozymes
}

\author{
Chan Jung Lee*, Jong Tae Lee ${ }^{1}$, Yeong Tae Kim², Chang Sung Jhune, \\ Jong Chun Cheong and Wan Park \\ Mushroom Research Division, National Institute of Horticultural \& Herbal Science, Rural Development Administration, \\ Suwon 441-707, Korea \\ ${ }^{1}$ Onion Research Institute, Gyeongnam Agricultural Research and Extension Services, Changnyeong 635-821, Korea \\ ${ }^{2}$ Genomics Division, National Academy of Agricultural Science, Rural Development Administration, \\ Suwon 441-707, Korea \\ ${ }^{3}$ School of Life Sciences and Biotechnology, Kyungpook National University, Daegu 702-701, Korea \\ (Received on October 5, 2011; Revised on February 20, 2012; Accepted on September 24, 2012)
}

\begin{abstract}
Burkholderia gladioli pv. alliicola $\mathrm{CH} 1$ showed typical soft rot symptoms at higher than $20^{\circ} \mathrm{C}$ but very weak soft rot symptoms at temperature under $10^{\circ} \mathrm{C}$. Among the nine agro-chemicals, oxolinic acid WP, streptomycin + copper hydroxide WP and streptomycin WP were found to be effective for the inhibition of the pathogen in vitro. The results of scanning electron microscopic investigation showed that onion bulbs was macerated by infection of $B$. gladioli pv. alliicola CH1. B. gladioli pv. alliicola CH1 was able to produce polygalacturonase but did not produce pectin lyase and carboxymethylcellulase. In analysis of the polygalacturonase activity of the isolated pectin-degradation enzymes from B. gladioli pv. alliicola $\mathrm{CH} 1$ total protein, three activity bands $45 \mathrm{kDa}, 35 \mathrm{kDa}$, and $29 \mathrm{kDa}$ were detected by the direct (or in-gel) activity staining on SDS-PAGE.
\end{abstract}

Keywords : Burkholderia gladioli pv. alliicola, Polygaractronase, SDS-PAGE

펙틴(pectin)은 식물체에서 $1 \%$ 정도를 차지하고 식물세 포벽의 중층과 1 차 세포벽을 구성하는 중요한 요소이며 식물체의 생리 및 병원성에 중요한 역할을 하고 식물 생 육에 필수적인 역할을 한다. 병원균의 감염에 의해 식물 의 조직이 무르고 세포벽의 구조가 변형된다는 것은 펙 틴분해효소 때문이며, 이는 식물의 병을 일으키는데 중요 한 역할을 한다는 것을 시사해 준다. 무름병의 중요한 증

*Corresponding author

Phone) +82-43-871-5711, Fax) +82-43-871-5711

Email) lchanj@korea.kr
상은 병원세균에 의해 분비되는 효소의 작용에 의해 식 물 조직이 물러지는 것이다. 이 분비 효소들은 cellulase, pectinase, polygalacturonase(PGase), protease 등(Fukumori 등, 1988)으로 식물세포벽의 구성물을 붕괴할 수 있으며, 대부분의 식물 병원균이 이들 효소를 분비하여 식물 조 직을 분해하는 능력 때문에 식물 병원성과 관련된 많은 연구가 이루어지고 있다(Collmer, 1986; Daniels 등, 1988). 양파에 부패병을 일으키는 주요 원인균으로 Pseudomonas gladioli pv. alliicola(Burkholder, 1942), Pseudomonas cepacia(Burkholder, 1950), Pseudomonas aeruginosa (Cother 등, 1976), Erwinia carotovora subsp. carotovora (1901) 
등 4종의 세균과, 그 외 양파의 부패와 연관이 있으면서 병원성이 조금 낮은 다수의 세균이 알려져 있다(Kawamoto 와 Lorbeer, 1964). 그런데 P. gladioli는 Yabuuchi 등(1992) 에 의해 Burkholderia gladioli로 재분류되었다. 국내에서 는 E. carotovora subsp. carotovora, E. rhaponticiae, E. chrysanthemi, P. marginalis pv. marginalis, P. cepacia, 그리 고 P. syringae가 Han과 Choi(1989)에 의해 양파 무름병 병 원균으로 보고되었다. 최근 Lee 등(2005)이 Burkholderia gladioli pv. alliicola가 양파에 무름병을 일으키는 사실을 국내 최초로 보고하였으며, 본 연구에서는 이 병원균의 약제 감수성, 감염조직의 변화 및 세포벽분해효소의 분비 특성, 펙틴분해효소 isozyme으로 추정되는 활성대 등을 조사하여 그 결과를 보고하고자 한다.

온도에 따른 병원성. 병원성 검정은 Maher과 Kelman (1983)이 사용한 방법을 약간 변형하여 사용하였으며, 순 수 분리한 세균을 nutrient agar 평판배지에서 24시간 배 양한 후 약 $7 \times 10^{8} \mathrm{cfu} / \mathrm{ml}$ 농도가 되도록 멸균수로 희석 하여 접종원으로 사용하였다. 온도에 따른 무름병의 진전 과정을 보기 위하여 건전한 양파 인편을 $1 \%$ sodium hypochloride로 표면 살균한 후 멸균증류수로 수회 세척 하여 물기를 제거하고 $100 \mu \mathrm{l}$ pipette tip으로 깊이 $20 \mathrm{~mm}$ 의 구멍을 만들어 $10 \mu \mathrm{l}$ 의 Burkholderia gladioli pv. alliicola 현탁액을 주입한 후 baseline으로 밀봉하고 랩으 로 쌌다. 접종된 시료를 멸균상자에 넣어 $5^{\circ} \mathrm{C}, 10^{\circ} \mathrm{C}, 20^{\circ} \mathrm{C}$, $30^{\circ} \mathrm{C}$ 의 항온기에 10 일간 보관 후 무름병 정도를 조사한 결과(Fig. 1$), 20^{\circ} \mathrm{C}$ 이상에서는 전형적인 양파 무름병의 증상을 보이면서 심하게 부패하였지만 $10^{\circ} \mathrm{C}$ 이하에서는 일부 조직의 무름증상을 보였지만 겉으로는 건전하게 보 였다. 또한 감자, 당근과 토마토에도 같은 방법으로 접종 하면 역시 조직이 물러지는 현상을 관찰할 수 있었다. 온 도에 따른 이 균의 무름병의 진전을 본 결과 $10^{\circ} \mathrm{C}$ 이하 에서는 병의 진전과정이 더디게 나타나 양파의 저온저장 이 효과적인 저장수단으로 생각된다.

감염에 의한 양파조직의 변화. B. gladioi pv. alliicola $\mathrm{CH} 1$ 의 감염에 의한 양파조직의 변화를 살펴보기 위하여 신선한 양파 인편에 B. gladioi pv. alliicola $\mathrm{CH} 1$ 을 접종 한 후 $30^{\circ} \mathrm{C}$ 에 두고 시간별로 양파조직의 변화를 광학현 미경으로 관찰하였다. 접종 후 24시간, 48시간이 지난 조 직은 정상조직에 비하여 세포조직이 많이 파괴된 것을 볼 수 있었고 특히 48시간이 지난 후의 양파조직은 세포를 관찰할 수가 없을 정도로 조직이 많이 파괴되었다. 이를 주사전자현미경으로 관찰한 결과는 Fig. 2와 같다. 접종 후 48시간이 지난 양파는 정상조직에 비해 조직의 붕괴 가 많이 일어나 세포조직의 위축을 볼 수 있었다.

약제 감수성. 세균병 방제약제로 등록되어 있는 여러 약제에 대한 B. gladioi pv. alliicola $\mathrm{CH} 1$ 의 감수성을 조 사한 결과 시험에 사용한 9개 약제들 중에서 oxolinic acid $\mathrm{WP}$ 는 $200 \mathrm{ppm}$ 에서도 $71 \mathrm{~mm}$ 의 저지대를 나타내어 가장

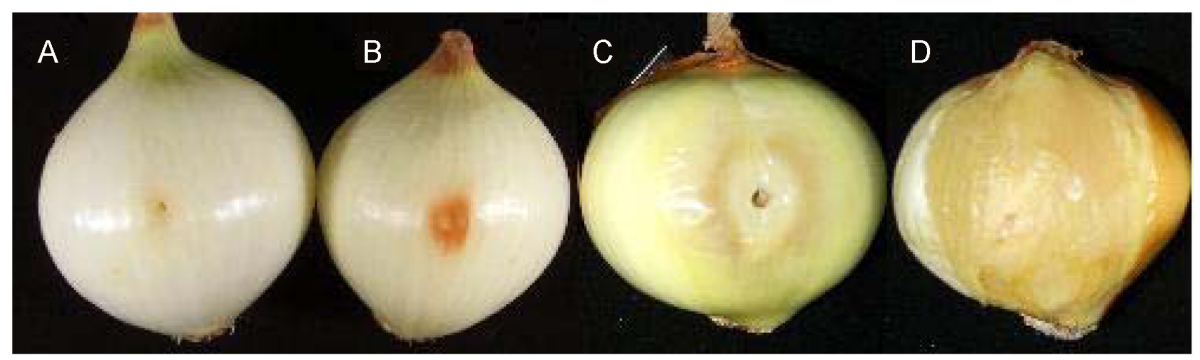

Fig. 1. Effect of the temperature on the ability of Burkholderia gladioi pv. alliicola $\mathrm{CH} 1$ to cause onion tissue maceration at 10 days after inoculation. (A) $5^{\circ} \mathrm{C}$. (B) $10^{\circ} \mathrm{C}$. (C) $20^{\circ} \mathrm{C}$. (D) $30^{\circ} \mathrm{C}$.

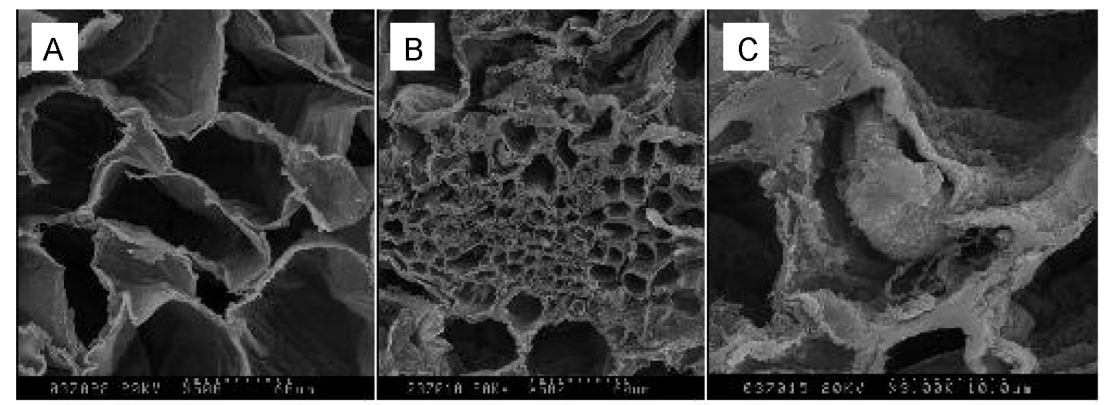

Fig. 2. Episcopical examination of healthy and inoculated onion surface structures by scanning electron microscopy. (A) a healthy onion tissue $(\times 500)$. (B, C) an inoculated tissue after $48 \mathrm{hr}$ of incubation $(\times 500, \times 3,000)$. 
Table 1. Effect of chemicals on growth of Burkholderia gladioi pv. alliicola $\mathrm{CH} 1$

\begin{tabular}{|c|c|c|c|}
\hline Common name ${ }^{a}$ & Active ingredient & $\begin{array}{l}\text { Concentration } \\
\text { (ppm) }\end{array}$ & $\begin{array}{c}\text { Diameter of inhibition } \\
\text { zone }(\mathrm{mm})\end{array}$ \\
\hline Kasugamycin SL & kasugamycin $2.3 \%$ & $\begin{array}{l}600 \\
400 \\
200\end{array}$ & $\begin{array}{l}10 \\
10 \\
10\end{array}$ \\
\hline $\begin{array}{l}\text { Streptomycin sulfate } \\
\text { oxytetracyclin WP }\end{array}$ & $\begin{array}{l}\text { streptomycin sulfate } 18.8 \% \\
\quad+\text { oxytetracyclin } 1.5 \%\end{array}$ & $\begin{array}{l}600 \\
400 \\
200\end{array}$ & $\begin{array}{l}15 \\
10 \\
10\end{array}$ \\
\hline Oxolinic acid WP & oxolinic acid $20 \%$ & $\begin{array}{l}600 \\
400 \\
200\end{array}$ & $\begin{array}{c}100 \\
81 \\
71\end{array}$ \\
\hline Validamycin-A SL & validamycin-A $5 \%$ & $\begin{array}{l}600 \\
400 \\
200\end{array}$ & $\begin{array}{c}15 \\
10 \\
0\end{array}$ \\
\hline $\begin{array}{c}\text { Streptomycin · } \\
\text { copper hydroxide WP }\end{array}$ & $\begin{aligned} & \text { streptomycin } 10 \% \\
+ & \text { copper hydroxide } 50 \%\end{aligned}$ & $\begin{array}{l}600 \\
400 \\
200\end{array}$ & $\begin{array}{l}60 \\
20 \\
12\end{array}$ \\
\hline Streptomycin WP & streptomycin $20 \%$ & $\begin{array}{l}600 \\
400 \\
200\end{array}$ & $\begin{array}{l}70 \\
35 \\
15\end{array}$ \\
\hline $\begin{array}{c}\text { Kasugamycin } \\
\text { copper oxychloride WP }\end{array}$ & $\begin{array}{l}\text { kasugamycin } 5.75 \%+ \\
\text { copper oxychloride } 45 \%\end{array}$ & $\begin{array}{l}600 \\
400 \\
200\end{array}$ & $\begin{array}{l}15 \\
10 \\
10\end{array}$ \\
\hline $\begin{array}{c}\text { Dithianon } \\
\text { copper oxychloride WP }\end{array}$ & $\begin{array}{c}\text { dithianon } 13 \%+ \\
\text { copper oxychloride } 42 \%\end{array}$ & $\begin{array}{l}600 \\
400 \\
200\end{array}$ & $\begin{array}{l}0 \\
0 \\
0\end{array}$ \\
\hline Dithianon WP & dithianon $75 \%$ & $\begin{array}{l}600 \\
400 \\
200\end{array}$ & $\begin{array}{l}15 \\
15 \\
10\end{array}$ \\
\hline
\end{tabular}

${ }^{a}$ WP: wettable powder, SL: soluble concentrate.

효과가 좋았고, streptomycin + copper hydroxide WP와 streptomycin WP는 $600 \mathrm{ppm}$ 에서 각각 $60 \mathrm{~mm}$ 와 $70 \mathrm{~mm}$ 의 저지대를 나타내었다. 이들 외에 kasugamycin SL 등 6 개의 약제들은 거의 효과가 없는 것으로 나타났다(Table 1).

병원균의 효소생성. 효소의 활성측정을 위하여 효소생 산배지에 균을 배양하여 원심분리에 의해 균체를 제거하 고 그 상징액을 세포 외로 분비된 효소원으로 사용하였 다. 필요에 따라 상징액을 Centricon-50 concentrator (Amicon, Beverly, Mass)로 농축하여 사용하였다. 펙틴질 분해효소인 polygalacturonase 활성은 polygalacturonic acid 를 기질로 사용하였고, carboxymethylcellulase 활성은 carboxymethylcellulose를 기질로 사용하여 실험하였다. 양 파에 무름병을 일으키는 B. gladioi pv. alliicola $\mathrm{CH} 1$ 균 주로부터 식물조직의 연화, 부패에 관여하는 것으로 알려 진 섬유소 및 펙틴질 분해효소의 생산능을 조사한 결과, 섬유소 분해활성의 carboxymethylcellulase 활성은 검출되 지 않았으나, 펙틴질 분해활성은 검출할 수 있었다. 그러
나 펙틴질 분해활성 중에서 pectin(pectate) lyase의 활성 은 검출되지 않았고 polygalacturonase 활성만 검출할 수 있었는데, 분리 균이 그람 음성균임에도 불구하고 polygalacturonase 활성의 대부분을 배양액 중에서 검출할 수 있어 이 효소는 세포 밖으로 분비되는 분비성 효소로 밝혀졌다. 이러한 사실은 펙틴질을 주성분으로 하는 식물 조직의 중간 라멜라층의 분해가 섬유소를 주성분으로 하 는 식물세포벽 분해보다도 더 밀접하게 부패와 관련이 있 는 것으로 생각된다. 양파의 무름증상과 관련하여 $\mathrm{Obi}$ 와 Umezurike(1981)은 Pseudomonas cepacia와 Bacillus polymyxa가 매우 약하지만 PGase 활성을 가진다고 보고 하였으며, Ulrich(1975)는 Pseudomonas cepacia의 endopolygalacturonase가 양파의 조직을 붕괴시킨다고 하였고, Ishii(1976)는 Aspergillus japanicus 의 endo-pectin lyase가 양파의 조직을 빠르게 붕괴시킨다고 보고하였다.

효소의 분비 특성. 병원균 $B$. gladioi pv. alliicola $\mathrm{CH} 1$ 균주의 생육특성인 $\mathrm{pH}$, 세포밀도와 조효소 활성도를 경 


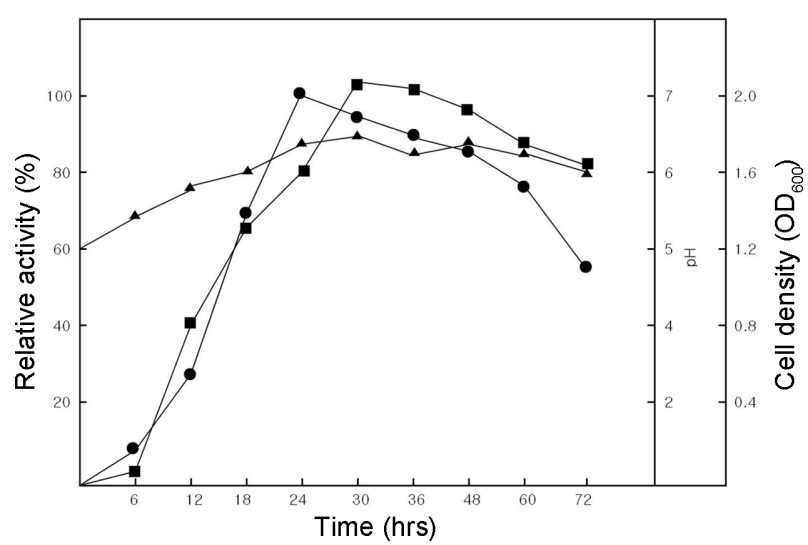

Fig. 3. Change of cell growth and enzyme activity in PGA broth.

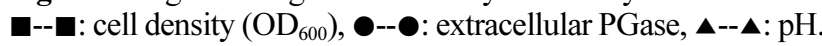
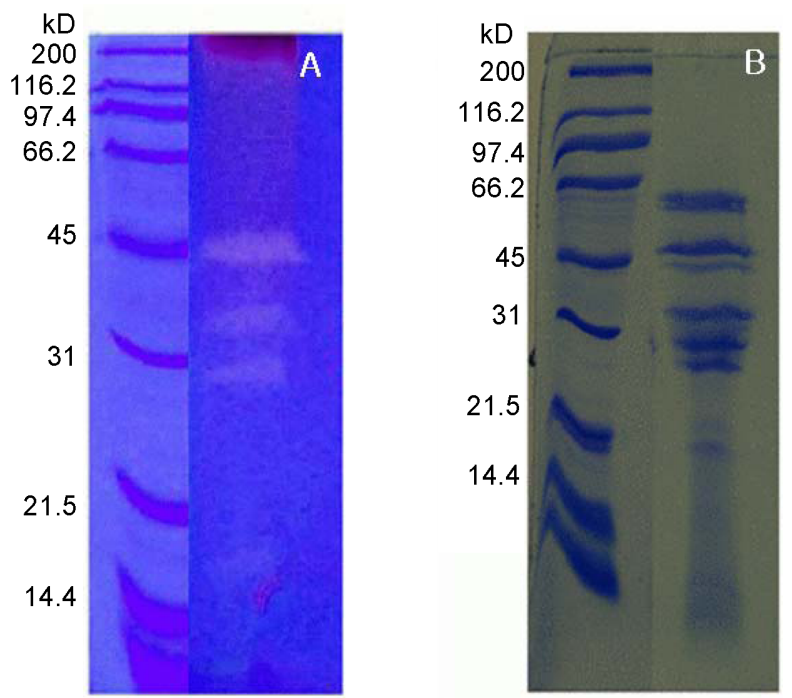

Fig. 4. Detection of polygalacturonase molecular weight of Burkholderia gladioi pv. alliicola $\mathrm{CH} 1$ by PGA-SDS-PAGE (A) and SDS-PAGE (B) method.

시적으로 측정한 결과는 Fig. 3과 같다. B. gladioi pv. alliicola $\mathrm{CH} 1$ 의 생육시간별 세포밀도를 $\mathrm{OD}_{600}$ 에서 측정 한 결과 30 시간 후 흡광도가 정지기에 도달했으며, 그 후 점차적으로 줄어드는 일반적인 세균의 생육상과 같았으 며, 배지의 $\mathrm{pH}$ 변화는 거의 없었다. 체외효소는 시간별로 활성을 측정하여 최고치를 100 으로 두고 상대적인 활성 도를 구하였다. 18 시간까지 급속한 효소반응을 보였고, 24시간 후에 최고치를 보인 후 큰 변화 없이 지속적인 효 소활성을 나타냈으며, 효소의 생성은 균의 생육과 거의 일치하는 것으로 나타났다.

펙틴 분해효소의 분자량 결정. B. gladioi pv. alliicola $\mathrm{CH} 1$ 이 생성하는 polygalacturonase의 분자량을 알아보기 위하여 McKeon(1988)에 의한 polygalacturonase의 직접 활
성 염색법에 따라 분리균이 분비하는 효소단백질을 $12.5 \%$ polyacrylamide, $2.7 \%$ cross-linked, $0.375 \mathrm{M}$ Tris- $\mathrm{HCl}(\mathrm{pH}$ 8.8), $0.1 \%$ SDS, $0.67 \mathrm{mg} / \mathrm{ml}$ polygalacturonate와 $100 \mu \mathrm{g} / \mathrm{ml}$ fibrinogen을 함유한 acrylamide gel 상에서 SDS-PAGE로 분석한 결과 3 개 $(45 \mathrm{kD}, 35 \mathrm{kD}, 29 \mathrm{kD})$ 의 활성 밴드를 관찰할 수 있었다(Fig. 4). 분리균 B. gladioi pv. alliicola $\mathrm{CH} 1$ 은 한 종류가 아닌 적어도 분자량이 서로 다른 세 종 류 이상의 polygalacturonase를 생성하여 세포 밖으로 분 비하는 것을 알 수 있었다. 이와 같이 양파에 세균성 무 름병을 일으키는 Burkholderia gladioli pv. alliicola는 양 파의 조직을 분해하는 polygalacturonase를 분비하여 독자 적으로 혹은 다른 효소와 상호작용을 통해 병원성에 영 향을 주는 것으로 생각한다. Ralstonia solanacearum는 $73 \mathrm{kDa}($ Allen 등, 1991)와 $33.5 \mathrm{kDa}$ (Cervone 등, 1986)의 exo-PGases을 분비하고, Sclerotinia sclerotiorum는 $43 \mathrm{kDa}$ (Gabriel 등, 1991)의 exo-PGases를 분비한다고 하였다. 앞 으로 계속적인 실험을 통하여 polygalacturonase 효소생성 에 관여하는 유전자의 클로닝 및 분비 효소를 정제하여 그 특성과 병원성과의 상관관계를 조사할 것이다.

\section{요 약}

양파 무름병 병원균인 Burkholder gladioli pv. allicola $\mathrm{CH} 1$ 을 양파에 접종했을 때 $20^{\circ} \mathrm{C}$ 이상에서는 전형적인 양 파 무름병 증상을 보이면서 심하게 부패하였지만, $10^{\circ} \mathrm{C}$ 이하에서는 일부 조직이 무름증상을 보였지만 겉으로는 건전하게 보였다. B. gladioli pv. allicola $\mathrm{CH} 1$ 은 oxolinic acid WP, streptomycin + copper hydroxide WP와 Streptomycin $\mathrm{WP}$ 에 강한 감수성을 보였다. 분비효소 중 펙틴질 분해효 소의 활성은 검출할 수 있었지만, 섬유소 분해효소인 carboxymethylcellulase 활성은 검출되지 않았다. 그러나 펙틴질 분해활성 중에서 pectin(pectate) lyase의 활성은 검 출되지 않고 polygalacturonase 활성만 검출할 수 있었다. $\mathrm{PGA}$ 액체배지에서 체외 효소는 18 시간까지 급속한 효소 반응을 보였으며, 24 시간 후에 최고치를 가진 후 계속적인 활성을 가졌으며 효소의 생성은 균의 생육과 거의 일치하 는 것으로 나타났다. PGA-SDS-PAGE에 의한 섬유소분해 효소 직접활성 염색법을 이용하여 3종류의 polygalacturonase isozyme으로 추정되는 $45 \mathrm{kDa}, 35 \mathrm{kDa}, 29 \mathrm{kDa}$ 크기의 활 성밴드를 관찰할 수 있었다.

\section{References}

Allen, C., Huang, Y. and Sequeira, L. 1991. Cloning of genes 
affecting polygalacturonase production in Pseudomonas solanacearum. Mol. Plant-Microbe Interact. 4: 147-154.

Burkholder, W. H. 1942. Three bacterial plant pathogens: Phytomonas caryophylli sp. n., Phytomonas alliicola sp. n., and Phytomonas manihotis (Collmer, A. 1986. The role of pectic enzymes in plant pathogenesis. Ann. Rev. Phytopathol. 24: 383-409.

Burkholder, W. H. 1950. Sour skin, a bacterial rot of onion bulbs. Phytopathology 40: 115-117.

Cervone, F., Lorenzo, G. D. E., Salvi, G. and Camardella, L. 1986. In: Biology and Molecular Biology of Plant-Pathogen Interactions, ed. by J. Bailey, Vol. H1, pp. 385-392. SpringerVerlag, Berlin/Heidelberg.

Collmer, A. 1986. The role of pectic enzymes in plant pathogenesis. Ann. Rev. Phytopathol. 24: 383-409.

Cother, E. J., Darbyshire, B. and Brewer, J. 1976. Pseudomonas aeruginosa: Cause of internal brown rot of onion. Phytopathology 66: 828-834.

Daniels, M. J., Dow, J. M. and Osbourn, A. E. 1988. Molecular genetics of phytopathogenicity in phytopathogenic bacteria. Ann. Rev. Phytopathol. 26: 285-312.

Fukumori, F., Kudo, T., Sashihara, N., Nagata, Y., Ito, K. and Horikoshi, K. 1988. The third cellulase of alkalophilic Bacillus sp. strain N-4: evolutionary relationships within the cel gene family. Biosci. Biotech. Biochem. 50: 45-51.

Gabriel, W., Keon, J. P. R. and Turner, G. 1991. Purification and characterization of two endopolygalacturonases from Sclerotinia sclerotiorum. Biochimica et Biophysica Acta. 1073: 43-48.

Han, K. S. and Choi, J. E. 1989. Studies on the bacterial soft rot disease of Lilliaceae crops : 1. Identification of Erwinia causing soft rot of onion. J. Agri. Sci. Chungnam Nat'l. Univ.
16: 19-25. (In Korean)

Ishii, S. 1976. Enzyme maceration of plant tissues by endo-pectin lyase and endo-polygalacturonase from Aspergillus japanicus. Phytopathology 66: 281-289.

Jones, L. R. 1901. A soft rot of carrot and other vegetables caused by Bacillus carotovorus. Vermont Agric. Exp. Station Rep. 13: 299-332.

Kawamoto, S. O. and Lorbeer, J. W. 1964. Selective isolation of soft rot bacteria of onion. Phytopathology 54: 897. (Abstract)

Lee, C. J., Lee, J. T., Kwon, J. H., Kim, B. C. and Park, W. 2005. Occurrence of bacterial soft rot of onion plants caused by Burkholderia gladioli pv. alliicola in Korea. Aus. Plant Pathol. 34: 287-292.

Maher, E. A. and Kelman, A. 1983. Oxygen status of potato tuber tissue in relation to maceration by pectic enzymes of Erwinia carotovora. Phytopathology 73: 536-539.

MeKeon, T. A. 1998. Activity stain for polygalacturonase. $J$. Chromatogr. 455: 376-381.

Obi, S. K. C. and Umerzurike, G. M. 1981. Pectic enzyme activities of bacteria associated with rotted onions (Allium cepa). Appl. Environ. Microbiol. 42: 585-589.

Ulrich, J. M. 1975. Pectic enzymes of Pseudomonas cepacia and penetration of polygalacturonase into cells. Physiol. Plant Pathol. 5: 37-44.

Yabuuchi, E., Kosako, Y., Oyaizu, H., Yano, I., Hotta, H., Hashimoto, Y., Ezaki, T. and Arakawa, M. 1992. Proposal of Burkholderia gen. nov. and transfer of seven species of the genus Pseudomonas homology group II to the new genus, with the type species Burkholderia cepacia (Palleroni and Holmes 1981) comb. nov. Microbiol. Immunol. 36: 12511275 . 